PEDAGOGISK FORSKNING I SVERIGE Vol. 25 No. 12020 ISSN 1401-6788

\title{
Debatt
}

\section{Vad talar vi om när vi talar om praktiknära forskning?}

Margareta Serder

Malmö universitet

Martin Malmström

Lunds universitet

I de många aktiviteter och samtal kring samverkan för praktiknära forskning som har följt på den nationella försöksverksamheten "ULF" (U2015/03573/UH, U2017/01129/UH), Skolforskningsinstitutets tillkomst och SOU-betänkandet Forska tillsammans, sker mycket som är både spännande och lovande. De pedagoger, lektorer och skolledare som mobiliserats är många och de väntar, med fog, på att deras erfarenheter och kunskaper tas tillvara i pågående och planerade projekt. Här ryms höga förväntningar - men också, vill vi påstå, en rad potentiella motsättningar.

Motstridiga förväntningar skapas exempelvis genom att olika parter inte alltid menar samma sak med centrala begrepp. Inte minst $i$ kölvattnet av ULF, där en mängd samarbetsavtal mellan akademi och huvudmän för att gynna den praktiknära forskningen tar form, bör vi vara uppmärksamma på detta. Vad är det egentligen vi talar om när vi talar om praktiknära forskning?

Den minsta gemensamma nämnaren utifrån hur begreppet används i dag vore möjligen att den praktiknära forskningen genomförs som någon form av samarbete mellan forskare och praktiker. Ett av huvudsyftena med ULF är just att forskare och lärare ska driva projekt tillsammans. Det är emellertid en inte alldeles självklar definition. Som ett exempel kan nämnas att när den utbildningsvetenskapliga kommittén bildades strax efter millennieskiftet, initierades en satsning på praxisnära forskning, men snarare än att lärare skulle delta $\mathrm{i}$ forskningen, var utgångspunkten att forskningen ägde rum i praktiken. Kunskapsbildning var högsta prioritet (Aasen \& Prøitz, 2004). För en del kvarstår med stor sannolikhet den här tolkningen. 
Begreppet praktiknära forskning å andra sidan, tog form i svenska policydokument runt 2010 och några år senare i den mediala debatten, även om det förekommit i utbildningsvetenskapliga diskussioner även tidigare. I och med detta tycks innebörden ha snävats in. Forskningen ska vara praktikutvecklande som det heter i Forska tillsammans och leda till undervisning som i högre grad är evidensbaserad (SOU 2018:19; SOU 2016:38, s. 147).

Evidensbasering är alltså en aspekt av praktiknära skolforskning som tillkommit under senare år, samtidigt som den också i allt högre utsträckning präglar svensk utbildningspolicy (Sundberg \& Håkansson, 2015). Därigenom speglar den förväntningar om forskning som berättar vad som är rätt - vad som är fungerande och effektiva interventioner i praktiken som gör att kunskapsresultaten ökar (Biesta, 2010). Den praktiknära forskningens roll i evidenstraditionen förväntas vara förbättring och problemet som ska lösas är lärares förmenta tillkortakommanden i sin undervisning.

Läraren som forskare är dock ingen ny företeelse utan en del av en lång aktionsforskningstradition, sprungen ur socialpsykologen Kurt Lewins arbete. Han ville under 1940-talet låta praktiker delta i alla delar av forskningsprocessen. Forskningen syftade till förbättring av praktiken - men även av samhället i sig. Dessa emancipatoriska ideal följde med när aktionsforskningen anammades av utbildningsforskare, exempelvis britten Lawrence Stenhouse och den nordamerikanska lärarforskningsrörelsen. Gemensam var synen på lärare som forskare. För Stenhouse var det viktigt att läraren reflekterade över sin undervisning och hade förmågan att undersöka den. Samma inställning hade Cochran-Smith och Lytle (1993) som menade att läraren kan skapa en speciell sorts kunskap som forskare inte på egen hand kan nå.

Begreppet praktiknära forskning kan förstås som ett boundary object (Star \& Grieshemer, 1989), ett ofixerat någonting vars innebörd ges olika tolkningar i olika grupper och sammanhang, men som ändå tycks vara tillräckligt robust för att stå emot trycket från omvärlden och behålla en gemensam identitet $\mathrm{i}$ olika kontexter (ibid). I det diffusa gränsobjekt som praktiknära forskning utgör, ryms som vi beskrivit således två olika ideal. Det ena har involverade lärare som adress, vilka genom reflektion och delaktighet är medskapare av en mer mångfacetterad kunskap om undervisning och utbildningens plats $\mathrm{i}$ det omgivande samhället. Forskningen kan vara kontextbunden och lokal, men också ha giltighet utanför denna och ta sig an viktiga samhällsfrågor. Det andra idealet riktas också det mot klassrummet, men dess mål är att finna de rätta metoderna. Här ser vi en annan möjlig motsättning. För inte nog med att vi kan tänkas mena olika saker med begreppet - vi kanske också ser helt olika mål och medel.

Aktionsforskning kan delas in i tre dimensioner: professionell, personlig och politisk (Noffke, 1997; 2009). Medan den professionella har undervisningsförbättring som yttersta mål, syftar den personliga till att öka 
kunskapen om den egna praktiken och den politiska reser frågor om demokrati och sociala orättvisor. Susan Noffke menar att aktionsforskningen blivit en del av en global nyliberal reformrörelse med ansvarighet (accountability) och excellens i högsätet, där den bestäms av uppifrån kommande direktiv snarare än att vara den gräsrotsrörelse den ursprungligen var. Då riskerar den att bli en "iconoclastic commodity" i stället för en del av en social rörelse. Här ser vi en viktig skiljelinje värd att uppmärksamma: I talet om den praktiknära forskningen finns denna motsättning genom att den politiska dimensionen måste blicka utanför klassrummet: forskning om undervisning blir då istället forskning om utbildning.

En tendens som vi ser är att den praktiknära forskningen tillskrivs evidensens universalitet och allmängiltighet, som i mångt och mycket är på tvärs med praktikens uppenbara komplexitet och lokalbundenhet (Popkewitz, 2020). I utbildningsdebatten framstår praktiknära forskning som användbar och icke-ideologisk. Kanske är det också så att så länge den har höjda resultat som mål kan den passera som politiskt "ofarlig", i motsats till annan utbildningsvetenskaplig forskning (Lundahl \& Serder, i press).

Senare års satsningar tyder på att det sätts stor tilltro till vad den praktiknära forskningen ska kunna åstadkomma. Från fältet förväntningarnas sociologi (sociology of expectations) vet vi dock att höga förväntningar på teknologiska och vetenskapliga landvinningar ofta slutar i besvikelse (se t.ex. Borup, Brown, Konrad \& Van Lente, 2006). Införandet av nya forskningsprogram präglas inte sällan av ett slags "historisk amnesi"; tidigare besvikelser tenderar att glömmas bort.

Det är inget fel på att ha höga förväntningar eller att undersöka vad som fungerar och inte i ett klassrum. Men vad händer om frågan "vad fungerar?" snarare än "vad händer här?" blir den enda vägledande i den praktiknära forskningen? Vad blir kvar av aktionsforskningstraditionens politiska och personliga dimensioner om endast den professionella premieras i utbildningspolicy? Vilka spänningar finns mellan olika parters syn på praktiknära forskning och vad leder detta till? Vad kan vi lära av historien? Och, inte minst, vilka förväntningar är rimliga att ställa på den praktiknära forskningen?

\section{REFERENSER}

Aasen, Petter \& Prøitz, Tine S. (2004). Initiering, finansiering och förvaltning av praxisnära forskning: Sektormyndighetens roll $i$ svensk, utbildningsforskning. Oslo: NIFU Skriftserie $10 / 2004$. 
Biesta, Gert (2010). Why 'What Works’ Still Won’t Work: From Evidence-Based Education to Value-Based Education. Stud Philos Educ, 29, s. 491-503. DOI: 10.1007/s11217-010-9191-x

Borup, Mads, Brown, Nik, Konrad, Kornelia, \& Van Lente, Harro. (2006). The sociology of expectations in science and technology. Technology Analysis \& Strategic Management, 18(3-4), s. 285-298. DOI: 10.1080/09537320600777002.

Cochran-Smith, Marilyn \& Lytle, Susan L. (red.). (1993). Inside/ outside: Teacher research and knowledge. New York: Teachers College Press.

Lundahl, Christian \& Serder, Margareta (i press). Is PISA more important to school reforms than educational research? The selective use of authoritative references in media and in parliamentary debates. Nordic Journal of Studies in Educational Policy. (accepterad 23 januari 2020)

Noffke, Susan (1997). Professional, personal, and political dimensions of action research, i Apple, M. (red.), Review of research in education. Washington, DC: American Educational Research Association, s. 305-343.

Noffke, Susan (2009). Revisiting the professional, personal, and political dimensions of action research. The $S A G E$ handbook of educational action research. London: SAGE Publications Ltd, s. 6-23.

Popkewitz, Thomas S. (2020). The Impracticality of Practical Research: A History of Contemporary Sciences of Change that Conserve. Ann Arbor: University of Michigan Press.

SOU 2016:38. 2015 års skolkommission (2016). Samling för skolan: nationella målsättningar och utvecklingsområden för kunskap och likvärdighet: delbetänkande. Stockholm: Wolters Kluwer.

SOU 2018:19. Utredningen om praktiknära skolforskning i samverkan (2018). Forska tillsammans: samverkan för lärande och förbättring. Stockholm: Norstedts juridik.

Star, Susan \& Griesemer, James R. (1989). "Ecology, 'Translations' and Boundary Objects: Amateurs and Professionals in Berkeley's Museum of Vertebrate Zoology, 1907-39". Social Studies of Science, 19(3), s. 387-420. DOI: 10.1177/030631289019003001

Sundberg, Daniel \& Håkansson, Jan (2015). Utbildningsvetenskaplig forskning $i$ utbildningspolitiken: en analys av olike modeller för mediering. Stockholm: Vetenskapsrådet.

U2015/03573/UH, U2017/01129/UH. Uppdrag om försöksverksambet med prak.tiknära forskning. Stockholm: Regeringskansliet. 